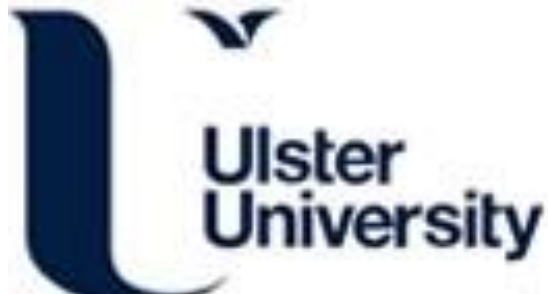

Molecular mechanisms of toxicity and cell damage by chemicals in a human pancreatic beta cell line, 1.1B4

Vasu, S., McClenaghan, N., \& Flatt, P. (2013). Molecular mechanisms of toxicity and cell damage by chemicals in a human pancreatic beta cell line, 1.1B4. Pancreas, 45(9), 1320-1329.

https://doi.org/10.1097/MPA.0000000000000645

Link to publication record in Ulster University Research Portal

Published in:

Pancreas

Publication Status:

Published (in print/issue): 01/10/2013

DOI:

10.1097/MPA.0000000000000645

\section{Document Version}

Author Accepted version

\section{General rights}

Copyright for the publications made accessible via Ulster University's Research Portal is retained by the author(s) and / or other copyright owners and it is a condition of accessing these publications that users recognise and abide by the legal requirements associated with these rights.

\section{Take down policy}

The Research Portal is Ulster University's institutional repository that provides access to Ulster's research outputs. Every effort has been made to ensure that content in the Research Portal does not infringe any person's rights, or applicable UK laws. If you discover content in the Research Portal that you believe breaches copyright or violates any law, please contact pure-support@ulster.ac.uk. 


\title{
Molecular Mechanisms of Toxicity and Cell Damage by Chemicals in a Human Pancreatic Beta Cell Line, 1.1B4
}

\author{
Srividya Vasu, PhD, Neville H. McClenaghan, PhD, and Peter R. Flatt, PhD
}

\begin{abstract}
Objectives: Mechanisms of toxicity and cell damage were investigated in novel clonal human pancreatic beta cell line, 1.1B4, after exposure to streptozotocin, alloxan, ninhydrin, and hydrogen peroxide.

Methods: Viability, DNA damage, insulin secretion/content, $\left[\mathrm{Ca}^{2+}\right]_{\mathrm{i}}$, and glucokinase/hexokinase, mRNA expression were measured by MTT assay, comet assay, radioimmunoassay, fluorometric imaging plate reader, enzymecoupled photometry, and real-time polymerase chain reaction, respectively. Results: Chemicals significantly reduced 1.1B4 cell viability in a time/ concentration-dependent manner. Chronic 18-hour exposure decreased cellular insulin, glucokinase, and hexokinase activities. Chemicals decreased transcription of INS, GCK, PCSK1, PCSK2, and GJA1 (involved in secretory function). Insulin release and $\left[\mathrm{Ca}^{2+}\right]_{\mathrm{i}}$ responses to nutrients and membrane-depolarizing agents were impaired. Streptozotocin and alloxan up-regulated transcription of genes, SOD1 and SOD2 (antioxidant enzymes). Ninhydrin and hydrogen peroxide up-regulated SOD2 transcription, whereas alloxan and hydrogen peroxide increased CAT transcription. Chemicals induced DNA damage, apoptosis, and increased caspase 3/7 activity. Streptozotocin and alloxan decreased transcription of $B C L 2$ while increasing transcription of $B A X$. Chemicals did not affect transcription of HSPA4 and HSPA5 and nitrite production.

Conclusions: $1.1 \mathrm{~B} 4$ cells represent a useful model of human beta cells. Chemicals impaired 1.1B4 cell secretory function and activated antioxidant defense and apoptotic pathways without activating endoplasmic reticulum stress response/nitrosative stress.
\end{abstract}

Key Words: 1.1B4 cells, apoptosis, beta cells, chemicals, oxidative stress, toxicity

(Pancreas 2016;00: 00-00)

C onsiderable effort has been made over the past 30 years to delineate mechanisms underlying beta cell death and protection in diabetes. Key in protective mechanisms are antioxidant enzymes, which are essential for detoxification of superoxide and hydroxyl radicals that are generated as a result of various biological processes including oxidative phosphorylation. ${ }^{1}$ Beta cells are highly metabolically active, and hence these defense mechanisms play a particularly important role in maintenance of cell function and survival. The majority of contributions to understanding of beta cell demise has come from studies using rodent beta cell lines to evaluate the effects of beta cell toxins, streptozotocin, alloxan, ninhydrin, and hydrogen peroxide. ${ }^{2}$

Alloxan monohydrate (5,6-dioxyuracil or 2,4,5,6-tetraoxypyrimidine) is an oxygenated pyrimidine derivative, which has a

From the SAAD Centre for Pharmacy and Diabetes, University of Ulster, Coleraine, Northern Ireland.

Received for publication July 31, 2015; accepted February 12, 2016.

Reprints: Srividya Vasu, PhD, SAAD Centre for Pharmacy and Diabetes, School of Biomedical Sciences, University of Ulster, Cromore Rd, Coleraine, BT52 1SA, Northern Ireland, United Kingdom (e-mail: s.vasu@ulster.ac.uk, s.vasu@outlook.com).

The project was partly funded by Vice Chancellor's Research Scholarship to S.V. and by University of Ulster strategic funding and the SAAD Trading and Contracting Company.

The authors declare no conflict of interest.

Copyright (C) 2016 Wolters Kluwer Health, Inc. All rights reserved. half-life of 1.5 minutes at $37^{\circ} \mathrm{C}$ and $\mathrm{pH} 7.4^{2}$ It mimics glucose in structure and enters beta cells via low-affinity GLUT2 glucose transporters. ${ }^{3}$ Once inside the cell, alloxan is reduced to dialuric acid, which takes part in redox cycling reactions with alloxan. Dialuric acid is oxidized to form hydrogen peroxide, superoxide radicals, hydroxyl radicals, and an alloxan radical, which is an important toxic intermediate in the redox cycling reactions. ${ }^{2}$ Ninhydrin, a stable analog of alloxan is nondiabetogenic in rats and is selectively toxic to pancreatic beta cells only at very low concentrations. At high concentrations, it is toxic to all types of endocrine cells and exocrine parenchymal cells. ${ }^{4}$

In contrast to alloxan compounds, streptozotocin (2-deoxy2-([(methylnitrosoamino) carbonyl] amino)-D-glucopyranose) is an antibiotic and antineoplastic agent produced by Streptomyces achromogenes. It is diabetogenic and used to induce diabetes in experimental animals by initiating selective destruction of beta cells. Streptozotocin is classed as an alkylating agent; it alkylates DNA and proteins once inside the cell. ${ }^{2,5}$ Like alloxan, it enters beta cells via low-affinity GLUT2 glucose transporters and has been shown to be nontoxic to RINm5F cells, which do not express GLUT2. ${ }^{5,6}$ Prolonged exposure to streptozotocin results in alkylation of mitochondrial DNA and proteins, which leads to reduced insulin secretory response to glucose and amino acids. ${ }^{7,8}$ Thus, apoptosis induced by excessive DNA damage caused by methylnitrosourea moiety of streptozotocin is the main mechanism of streptozotocin toxicity.

Unlike the other beta cell toxins, hydrogen peroxide is a harmful by-product of aerobic respiration and other vital biological processes. In phagocytic immune cells, NADPH (nicotinamide adenine dinucleotide phosphate) oxidase induces formation of hydrogen peroxide that acts as cytotoxic agent. ${ }^{9}$ In nonimmune cells, NADPH oxidase induces generation of reactive oxygen species (ROS) that act as signaling molecules in processes including angiogenesis and insulin action. Hydrogen peroxide can also be transported from outside cells through aquaporins and by diffusion. Accumulation of hydrogen peroxide in cells results in chronic oxidative stress causing extensive cellular damage. Pancreatic beta cells are more susceptible to ROS because of very low expression of antioxidant enzymes especially catalase. This enzyme converts hydrogen peroxide to water and nascent oxygen, thereby preventing the harmful effects of hydroxyl radicals. ${ }^{10} \mathrm{An}$ tioxidants derived from the diet protect from oxidative stress, but it is the local concentrations of antioxidants in the vicinity of beta cells that determine the fate of insulin-secreting cells. ${ }^{9}$

Compared with rodent beta cell lines and primary tissue derived from animals, considerably less information has been gathered concerning actions of beta cell toxins on human islet cells due to scarcity of investigative material. Nevertheless, similarities and differences are evident when comparing animal and human beta cells. Cellular responses of the recently described human pancreatic beta cell line, 1.1B4, to lipotoxicity, glucotoxicity and cytokine toxicity were similar to primary human islets. ${ }^{11-13}$ In the present study, we investigated the cellular responses of 1.1B4 cells after chronic 18-hour exposure to streptozotocin, alloxan, ninhydrin, and hydrogen peroxide in terms of cell secretory function, gene expression, DNA integrity, and cell survival. These 
studies highlight key pathways involved in human beta cell dysfunction and survival in diabetes conditions.

\section{MATERIALS AND METHODS}

\section{Cell Culture and Viability}

Human electrofusion-derived 1.1B4 cells (available from PHE Culture Collections, Salisbury, United Kingdom; catalog $10012801)^{14}$ (passages 25-40) were routinely cultured in RPMI1640 medium (Gibco; Invitrogen, Paisley, United Kingdom) containing $11.1 \mathrm{mM}$ glucose, $10 \%$ (vol/vol) fetal bovine serum (Gibco; Invitrogen), and $1 \%(\mathrm{vol} / \mathrm{vol})$ antibiotics: penicillin $(100 \mathrm{U} / \mathrm{mL})$ and streptomycin $(0.1 \mathrm{mg} / \mathrm{L})$ (Gibco; Invitrogen), with $5 \% \mathrm{CO}_{2}$ and $95 \%$ air. The generation, culture, and basic characteristics of these cells have been described in detail elsewhere. ${ }^{1-16}$ For investigations of effects of chemicals, streptozotocin and alloxan were prepared in $0.01 \mathrm{~N} \mathrm{HCl}$ immediately before use. Ninhydrin and hydrogen peroxide were prepared in distilled water immediately before use. Viability of cells after exposure to chemicals was assessed by MTT assay. ${ }^{17}$

\section{Insulin Release, Insulin Content, Intracellular $\mathrm{Ca}^{2+}$, and Glucokinase}

1.1B4 cells were harvested and seeded at a density of 70,000 cells per well in 24-well plates and allowed to attach overnight. Following 18-hour exposure to chemicals, secretory function, gene expression, and other parameters were assessed. Cells were extracted using ice-cold acid ethanol (75\% vol/vol ethanol, $1.5 \%$

TABLE 1. Human Primers

\begin{tabular}{|c|c|c|c|}
\hline Gene Symbol (Accession No.) & Alias/Common Name & Primer Sequence $\left(5^{\prime}-n t-3^{\prime}\right)$ & Product Size, Base Pairs \\
\hline \multicolumn{4}{|l|}{ Secretory function } \\
\hline \multirow[t]{2}{*}{ INS (NM_000207) } & \multirow[t]{2}{*}{ Insulin } & F-TACCAGCATCTGCTCCCTCT & \multirow[t]{2}{*}{120} \\
\hline & & R-TGCTGGTTCAAGGGCTTTAT & \\
\hline \multirow[t]{2}{*}{ GCK (NM_000162) } & \multirow[t]{2}{*}{ Glucokinase } & F-GGACCAAGGGCTTCAAGGCC & \multirow[t]{2}{*}{207} \\
\hline & & R-CATGTAGCAGGCATTGCAGCC & \\
\hline \multirow[t]{2}{*}{ PCSK1 (NM_001177875) } & \multirow{2}{*}{$\begin{array}{l}\mathrm{PC} 1 / 3 \text {, proprotein convertase } \\
\text { subtilisin/kexin type } 1\end{array}$} & F-TCGCGCCTCCTAGCTCTTCGCA & \multirow[t]{2}{*}{173} \\
\hline & & R-GCAGACTCCAGGCTCTTCGCTC & \\
\hline \multirow[t]{2}{*}{ PCSK2 (NM_001201528) } & \multirow{2}{*}{$\begin{array}{l}\text { PC2, proprotein convertase } \\
\text { subtilisin/kexin type } 2\end{array}$} & F-TCGACCAGGTGGTGCGGGAT & \multirow[t]{2}{*}{137} \\
\hline & & R-AAAGGCGGATGTGCAGCGCT & \\
\hline \multirow[t]{2}{*}{ GJA1 (NM_000165) } & \multirow[t]{2}{*}{ Connexin $43 \mathrm{~A}$, gap junction protein 1} & F-GCTATTGTGAATGGGGTGCT & \multirow[t]{2}{*}{493} \\
\hline & & R-CTGCCAAAATTGGGAACACT & \\
\hline \multicolumn{4}{|l|}{ Antioxidant defense } \\
\hline \multirow[t]{2}{*}{ SOD1 (NM_000454) } & \multirow[t]{2}{*}{ Superoxide dismutase 1 (soluble) } & F-ACGGGGTGCTGGTTTGCGTC & \multirow[t]{2}{*}{121} \\
\hline & & R-TTCAGCACGCACACGGCCTT & \\
\hline \multirow[t]{2}{*}{ SOD2 (NM_000636) } & \multirow[t]{2}{*}{ Superoxide dismutase 2 , mitochondrial } & F-TCCAAGGGAAACACTCGGCTTT & \multirow[t]{2}{*}{95} \\
\hline & & R-ACCACTGGGTGACATCTACCAGA & \\
\hline \multirow[t]{2}{*}{ CAT (NM_001752) } & \multirow[t]{2}{*}{ Catalase } & F-CGTGCTGAATGAGGAACAGA & \multirow[t]{2}{*}{118} \\
\hline & & R-AGTCAGGGTGGACCTCAGTG & \\
\hline \multirow[t]{2}{*}{ GPX-1 (NM_000581) } & \multirow[t]{2}{*}{ Glutathione peroxidase 1} & F-TCCCTGCGGGGCAAGGTACTAC & 171 \\
\hline & & R-TTCGTTCTTGGCGTTCTCCTGATG & \\
\hline Apoptosis & & & \\
\hline BCL2 (NM_000633) & B cell lymphoma 2 & F-TGGAGAGCGTCAACCGGGAG & 160 \\
\hline & & R-ATCAAACAGAGGCCGCATGCTG & \\
\hline BAX (NM_004324) & BCL2-associated X protein & F-TGGACTTCCTCCGGGAGCGG & 167 \\
\hline & & R-CTGGGGGCCTCAGCCCATCT & \\
\hline MAPK10 (NM_002753.3) & Mitogen-activated protein kinase 10 & F-CAGCACAGGTGCAGCAGTGA & 140 \\
\hline & & R-AACCCAGGGGTCCTGCCGAG & \\
\hline NFKB1 (NM_003998) & Nuclear factor of $\kappa$ light polypeptide & F-CCTGGATGACTCTTGGGAAA & 173 \\
\hline & gene enhancer in B cells 1 & R-TCAGCCAGCTGTTTCATGTC & \\
\hline ER stress response & & & \\
\hline HSPA4 (NM_002154) & Hsp70, heat shock 70-kd protein 4 & F-AGCAGCGCTCTCGGTTGCAG & 133 \\
\hline & & R-AGACAGGACACGGACCCCCG & \\
\hline HSPA5 (NM_005347) & BiP, heat shock $70-k d$ protein 5 & F-TGCTGCTGCCCAACTGGCTG & 160 \\
\hline & & R-GAACACGCCGACGCAGGAGT & \\
\hline Reference gene & & & \\
\hline ACTB (NM_001101) & Actin, beta & F-AGAGCCTCGCCTTTGCCGATCC & 103 \\
\hline & & R-CACATGCCGGAGCCGTTGTCG & \\
\hline
\end{tabular}

Specific human primers were designed using Primer3 and BLAST. Primer sequences and product size are listed. Primers with efficiencies between $90 \%$ and $110 \%$ were used. 
$\mathrm{vol} / \mathrm{vol}$ concentrated $\mathrm{HCl}$ ) for assessment of insulin content. Insulin was measured by radioimmunoassay using human insulin standards and expressed as nanograms per million cells per 20 minutes (Sigma, Poole, United Kingdom). ${ }^{18}$ Intracellular $\mathrm{Ca}^{2+}$ responses were determined using fluorometric imaging plate reader calcium 5 assay kit (Molecular Devices, Sunnyvale, Calif) as described previously. ${ }^{19}$ Following exposure to chemicals, $\left[\mathrm{Ca}^{2+}\right]_{\mathrm{i}}$ responses to secretagogues were monitored using FlexStation scanning fluorimeter, and the area under the curve was calculated using GraphPad Prism (La Jolla, Calif). $\left[\mathrm{Ca}^{2+}\right]_{\mathrm{i}}$ responses to glucose $(5.6 \mathrm{mM})$ were used as baseline for comparing effects of secretagogues. Glucokinase and hexokinase activity was assessed using enzyme-coupled photometric assay. ${ }^{20}$

\section{Real-Time Reverse Transcription Polymerase Chain Reaction}

mRNA extraction and cDNA conversion were carried out using RNeasy mini kit (Qiagen, Manchester, United Kingdom) and Superscript II reverse transcriptase-RNase H kit (Invitrogen) following the manufacturer's instructions. For real-time reverse transcription polymerase chain reaction (PCR), reaction mix consisting of $12.5 \mu \mathrm{L}$ buffer (Quantifast SYBR green PCR kit; Qiagen), $1 \mu \mathrm{L}$ primers (forward and reverse, Table 1; Invitrogen), $1 \mu \mathrm{L}$ respective cDNA, and $9.5 \mu \mathrm{L}$ RNase-free water was used. Amplification conditions were set to $95^{\circ} \mathrm{C}$ for 5 minutes for initial denaturation, $95^{\circ} \mathrm{C}$ for 30 seconds for final denaturation, $58^{\circ} \mathrm{C}$ for 30 seconds for annealing, and $72^{\circ} \mathrm{C}$ for 30 seconds for 34 cycles for extension, followed by melting curve analysis at temperature range of $60^{\circ} \mathrm{C}$ to $90^{\circ} \mathrm{C}$. Realtime data were acquired using MiniOpticon 2-color real-time PCR detection system (BioRad, Hertfordshire, United Kingdom) and analyzed using $\Delta \Delta \mathrm{Ct}$ method, with mRNA expression normalized to $A C T B$ expression.

\section{Catalase Assay}

Following exposure to chemicals, catalase enzyme activity in cytoplasmic extracts was determined using Amplex red catalase assay kit (Molecular Probes; Invitrogen). Catalase activity in unknown samples was assessed using standards, with concentrations of catalase ranging from 62.5 to $1000 \mathrm{mU} / \mathrm{mL}$ and expressed as units per milligram of protein.

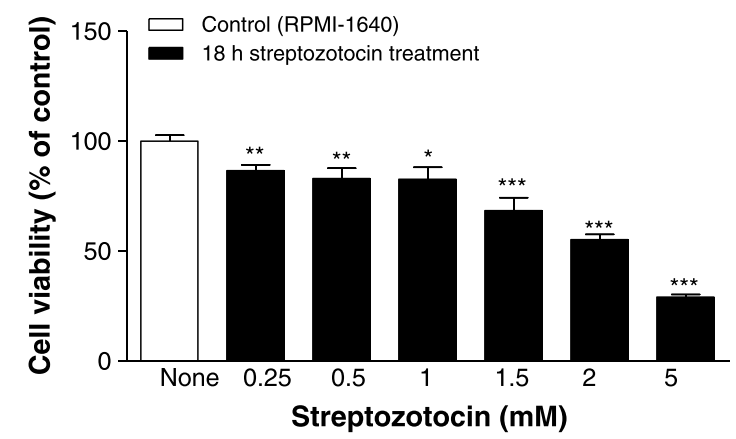

A

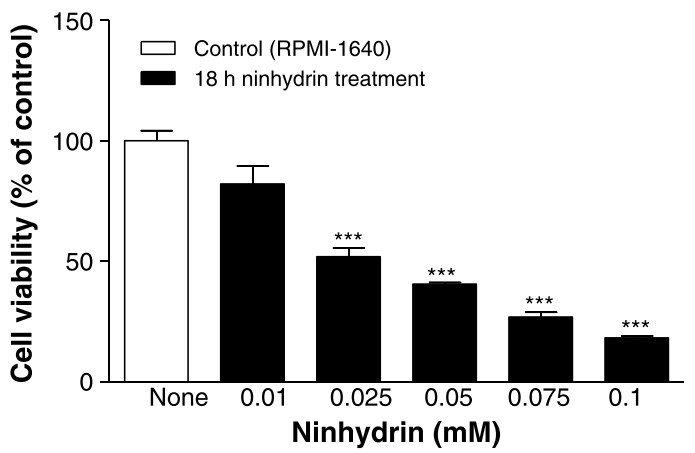

C

\begin{tabular}{|l|l|l|}
\hline Chemical & $\mathbf{L D}_{\mathbf{5 0}}(\mathbf{m M})$ for $\mathbf{~ h}$ exposure & $\mathbf{L D}_{\mathbf{5 0}}(\mathbf{m M})$ for $\mathbf{1 8} \mathbf{~ h}$ exposure \\
\hline Streptozotocin & 20 & 2.35 \\
\hline Alloxan & 12 & $>5$ \\
\hline Ninhydrin & 0.55 & 0.03 \\
\hline Hydrogen peroxide & 0.26 & 0.03 \\
\hline
\end{tabular}

$\mathrm{E}$

FIGURE 1. Cell viability of 1.1B4 cells after 18-hour exposure to streptozotocin (A), alloxan (B), ninhydrin (C), and hydrogen peroxide (D). $E$, Lethal dose 50 for 1 -hour exposure and 18-hour exposure to chemicals. Values are mean $\pm \operatorname{SEM}(\mathrm{n}=8) .{ }^{*} P<0.05,{ }^{* *} P<0.01$, $\star * * P<0.001$ compared with untreated control cells.

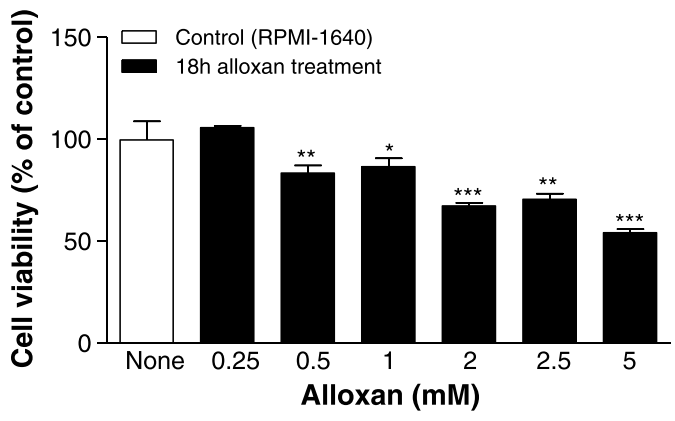

B

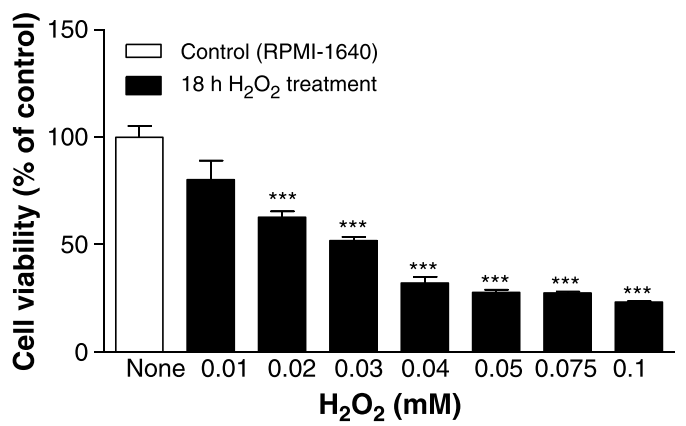

D

\section{.}




\section{Alkaline Comet Assay}

For analysis of DNA damage after exposure to chemicals, alkaline comet assay was carried out, ${ }^{21}$ with UV light exposure for 20 minutes as positive control. After comet assay, the gels were stained with DAPI $\left(4^{\prime}, 6\right.$-diamidino-2-phenylindole $)(100 \mu \mathrm{g} / \mathrm{mL})$ and viewed using epifluorescent microscope (model BX51; Olympus System Microscope; Olympus, Southend-on-Sea, United Kingdom). Extent of DNA damage was determined by CometScore software (TriTek Corp, Sumerduck, Va), with analyses of densitometric and geometric parameters including percent tail DNA and olive tail moment (product of tail length and fraction of total DNA in tail).

\section{Caspase Assay}

Apoptosis was assessed by determining caspase $3 / 7$ activity using caspase Glo 3/7 assay kit (Promega, Southampton, United Kingdom) according to the manufacturer's instructions. Briefly, after exposure to chemicals, 1.1B4 cells were lysed with RIPA buffer containing $150 \mathrm{mM} \mathrm{NaCl}, 1.0 \%$ Nonidet P-40, $0.5 \%$ sodium deoxycholate, $0.1 \%$ sodium dodecyl sulfate, and $50 \mathrm{mM}$ Tris $\mathrm{HCl}$ ( $\mathrm{pH} 7.6$ ) in the absence of protease inhibitor cocktail to protect caspase activity. The extracts were mixed with Caspase-Glo reagent and incubated for 1 hour, and luminescence was measured using Flexstation III (Molecular Devices, Sunnyvale, CA). Caspase 3/7 activity was expressed in terms of relative luminescence units.

\section{Nitrite Assay}

Nitrite production by 1.1B4 cells was determined using Griess reagent kit (Invitrogen). Briefly, Griess reagent was prepared by mixing equal amounts of sulfanilic acid and $N-(1-$ naphthyl) ethylenediamine. After 30 minutes' incubation with samples, absorbance was read at $548 \mathrm{~nm}$ using microplate reader (Molecular Devices).

\section{Acridine Orange/Ethidium Bromide Assay}

Apoptosis after exposure to chemicals was assessed using acridine orange/ethidium bromide, as described previously. ${ }^{13}$ Cells with bright green nuclei were designated healthy, whereas cells with dense green nuclei with evidence of chromatin condensation were designated early apoptotic. Cells with bright yellow nuclei and yellow cytoplasm were designated late apoptotic, and cells with orange/red nuclei with orange cytoplasm as late apoptotic.

\section{Statistical Analysis}

Results were analyzed in GraphPad PRISM (version 3.0) and presented as mean \pm SEM. Statistical analyses were carried out by unpaired Student $t$ test (nonparametric) (with 2-tailed $P$ values and $95 \%$ confidence intervals) and 1-way analysis of variance with Bonferroni post hoc test wherever applicable. Results were considered significant if $P<0.05$.

\section{RESULTS}

\section{Cellular Viability}

Chemicals caused a dose-dependent decrease in 1.1B4 cell viability after chronic 18 -hour exposure $(P<0.05, P<0.01$, $P<0.001$; Figs. 1A-D). Lethal dose $50 \%\left(\mathrm{LD}_{50}\right)$ was between 0.26 and $20 \mathrm{mM}$ for 1-hour exposure and between 0.03 and $2.35 \mathrm{mM}$ for 18-hour exposure to streptozotocin, ninhydrin, and hydrogen peroxide (Fig. $1 \mathrm{E}$ ). $\mathrm{LD}_{50}$ for alloxan toxicity was $12 \mathrm{mM}$ for 1-hour exposure and more than $5 \mathrm{mM}$ for 18-hour exposure (Fig. 1E).

\section{Insulin Secretion and Beta Cell Function}

Chemicals markedly reduced $1.1 \mathrm{~B} 4$ cellular insulin content, with the exception of alloxan $(P<0.01$; Fig. $2 \mathrm{~A})$. All chemicals

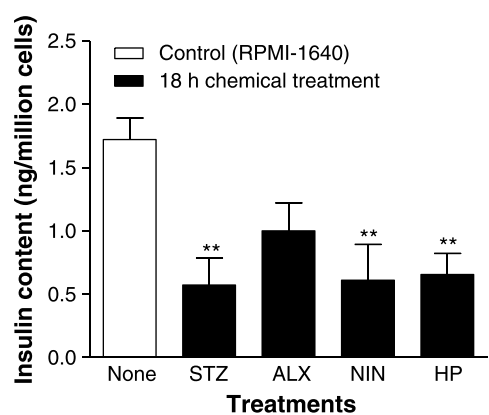

A

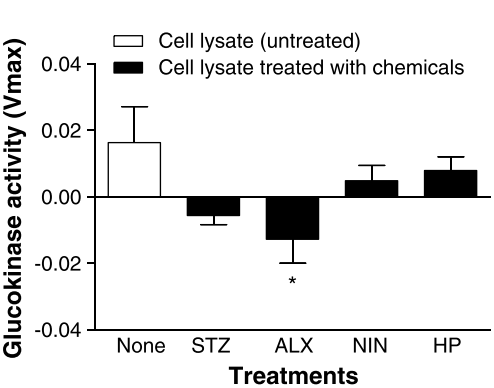

$\mathrm{D}$

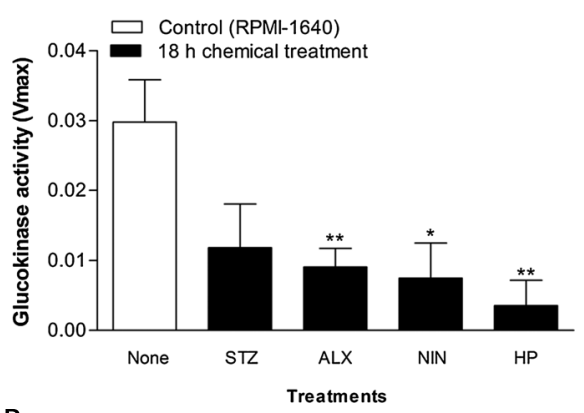

B

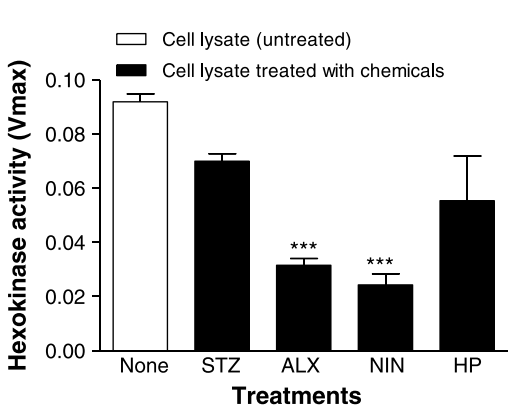

$\mathrm{E}$

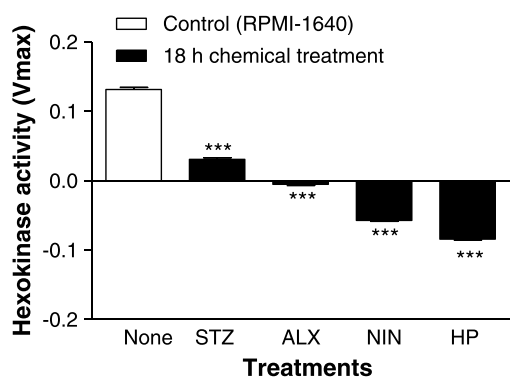

C

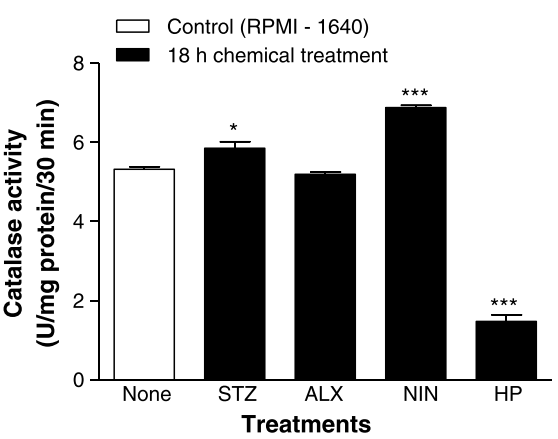

$\mathrm{F}$

FIGURE 2. Cellular insulin content (A), glucokinase (B), and hexokinase (C) activities of 1.1B4 cells after 18-hour exposure to chemicals (streptozotocin [STZ; $0.5 \mathrm{mM}$ ], alloxan [AX; $0.5 \mathrm{mM}$ ], ninhydrin [NIN; $25 \mu \mathrm{M}]$, hydrogen peroxide [HP; $30 \mu \mathrm{M}]$ ). Glucokinase (D) and hexokinase (E) activities after 5 minutes' incubation of 1.1B4 cell lysate with chemicals. Catalase activity (F) after chemical exposure is also shown. Values are mean $\pm \operatorname{SEM}(n=8)$. ${ }^{\star} P<0.05,{ }^{* *} P<0.01,{ }^{* \star *} P<0.001$ compared with untreated control cells. 
TABLE 2. 1.1B4 Cell Insulin Secretory Function After 18-Hour Exposure to Chemicals

Insulin Release, $\mathbf{n g} / \mathrm{million}$ cells per $20 \mathrm{~min}$

\begin{tabular}{|c|c|c|c|c|c|}
\hline Secretagogues & Control (RPMI-1640) & Streptozotocin $(0.5 \mathrm{mM})$ & Alloxan (0.5 mM) & Ninhydrin (0.025 mM) & $\mathrm{H}_{2} \mathrm{O}_{2}(0.03 \mathrm{mM})$ \\
\hline Glucose $(5.6 \mathrm{mM})$ & $0.12 \pm 0.01$ & $0.03 \pm 0.003^{*}$ & $0.03 \pm 0.001 *$ & $0.13 \pm 0.01$ & $0.1 \pm 0.01$ \\
\hline Glucose (16.7 mM) & $0.21 \pm 0.03^{\dagger}$ & $0.02 \pm 0.001^{*}$ & $0.03 \pm 0.002 *$ & $0.12 \pm 0.05$ & $0.13 \pm 0.03$ \\
\hline Alanine $(10 \mathrm{mM})$ & $0.28 \pm 0.03^{\ddagger}$ & $0.03 \pm 0.001 *$ & $0.04 \pm 0.004^{*}$ & $0.17 \pm 0.02^{\S}$ & $0.15 \pm 0.02^{\|}$ \\
\hline Arginine $(10 \mathrm{mM})$ & $0.27 \pm 0.03^{\ddagger}$ & $0.04 \pm 0.003^{*}$ & $0.06 \pm 0.004^{*}$ & $0.16 \pm 0.008^{\S}$ & $0.12 \pm 0.02^{\|}$ \\
\hline $\mathrm{KCl}(30 \mathrm{mM})$ & $0.45 \pm 0.03^{\ddagger}$ & $0.02 \pm 0.002 *$ & $0.04 \pm 0.002 *$ & $0.11 \pm 0.006^{*}$ & $0.14 \pm 0.02 *$ \\
\hline $\mathrm{CaCl}_{2} .2 \mathrm{H}_{2} \mathrm{O}(7.68 \mathrm{mM})$ & $1.00 \pm 0.06^{\ddagger}$ & $0.668 \pm 0.05 * \$$ & $0.88 \pm 0.02 * *$ & $0.35 \pm 0.06^{\| \top}$ & $0.25 \pm 0.05^{* \dagger}$ \\
\hline
\end{tabular}

After 18-hour exposure to chemicals in culture, 1.1B4 cells were stimulated with secretagogues for 20 minutes, and insulin release was measured by radioimmunoassay. Values are mean $\pm \operatorname{SEM}(\mathrm{n}=8)$.

$* P<0.001$ when compared with control culture (RPMI-1640).

${ }^{\dagger} P<0.05$ when compared with $5.6 \mathrm{mM}$ glucose.

${ }^{\star} P<0.001$ when compared with $5.6 \mathrm{mM}$ glucose.

${ }^{\S} P<0.05$ when compared with control culture (RPMI-1640).

${ }^{\|} P<0.01$ when compared with control culture (RPMI-1640).

${ }^{\text {I }} P<0.01$ when compared with $5.6 \mathrm{mM}$ glucose.

reduced glucokinase and hexokinase activities after chronic 18 -hour exposure $(P<0.05, P<0.01, P<0.001$; Figs. $2 \mathrm{~B}, \mathrm{C})$. On incubation of 1.1B4 cytoplasmic extract with chemicals, alloxan significantly reduced glucokinase and hexokinase activities within 5 minutes $(P<0.05, P<0.001$; Figs. 2D, E). Streptozotocin $(0.5 \mathrm{mM})$ and alloxan $(0.5 \mathrm{mM})$ abolished insulin secretory responses to glucose $(5.6$ and $16.7 \mathrm{mM})(P<0.001$; Table 2), whereas ninhydrin $(25 \mu \mathrm{M})$ and $\mathrm{H}_{2} \mathrm{O}_{2}(30 \mu \mathrm{M})$ did not affect insulin output. All chemicals decreased insulin secretory responses to alanine, arginine, $\mathrm{KCl}$, and elevated $\mathrm{Ca}^{2+}(P<0.05$, $P<0.01, P<0.001$; Table 2). As shown in Figure 3, the ability of these secretagogues to enhance intracellular $\mathrm{Ca}^{2+}$ was also impaired $(P<0.05, P<0.01, P<0.001 ;$ Fig. 3). Streptozotocin $(0.5 \mathrm{mM})$ and alloxan $(0.5 \mathrm{mM})$ significantly reduced transcription of INS, GCK, PCSK1, and GJAI $(P<0.05, P<0.01, P<0.001$; Table 3). Ninhydrin $(25 \mu \mathrm{M})$ and $\mathrm{H}_{2} \mathrm{O}_{2}(30 \mu \mathrm{M})$ did not affect expression of $G C K$ and PCSK2 (Table 3$)$. Ninhydrin $(25 \mu \mathrm{M})$ significantly increased transcription of $P C S K 1$, whereas $\mathrm{H}_{2} \mathrm{O}_{2}(30 \mu \mathrm{M})$ decreased GJAI $(P<0.001$ and $P<0.05$, respectively; Table 3$)$.

\section{Antioxidant Defense}

Streptozotocin $(0.5 \mathrm{mM})$ significantly up-regulated transcription of $S O D 1$ and $S O D 2$, whereas alloxan up-regulated transcription of SOD1, SOD2, and CAT $(P<0.05, P<0.01$,
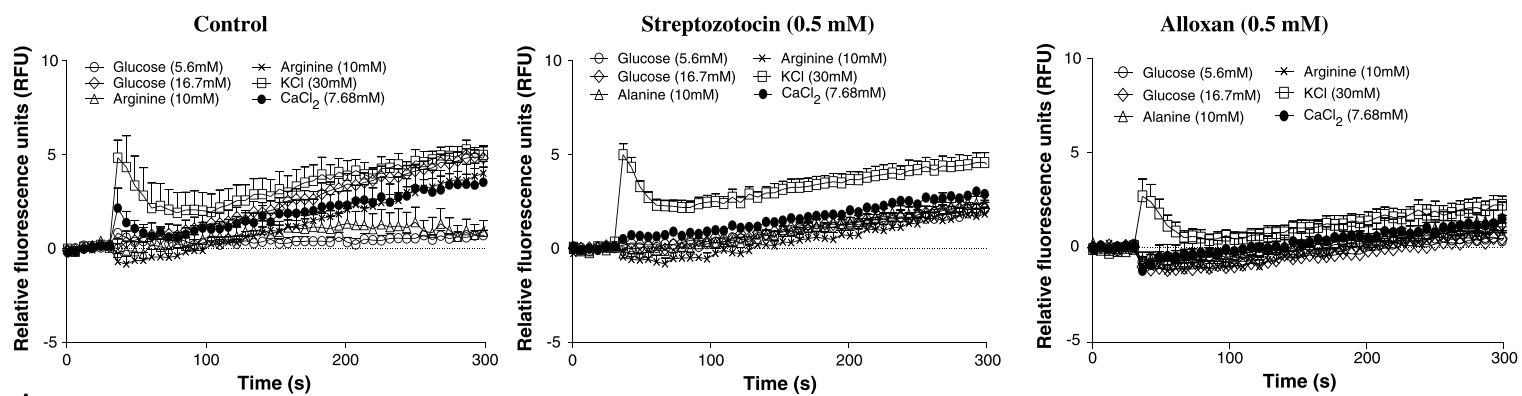

A
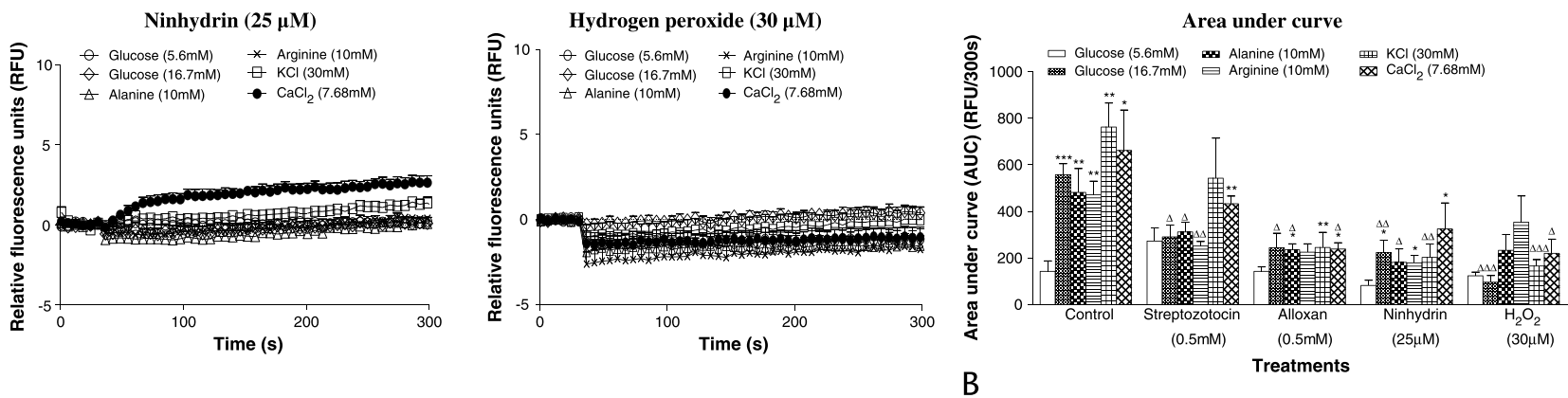

FIGURE 3. $\left[\mathrm{Ca}^{2+}\right]_{\mathrm{i}}$ responses of $1.1 \mathrm{~B} 4$ cells to glucose $(5.6 \mathrm{mM}, 16.7 \mathrm{mM}), 10 \mathrm{mM}$ alanine, $10 \mathrm{mM}$ arginine, $30 \mathrm{mM} \mathrm{KCl}$, elevated $7.68 \mathrm{mM} \mathrm{Ca}^{2+}$ after 18-hour exposure to chemicals. Temporal responses are shown in A. Data are expressed as area under the curve (B). Tests were performed at $5.6 \mathrm{mM}$ unless otherwise stated. Values are mean \pm SEM $(\mathrm{n}=6) .{ }^{*} p<0.05,{ }^{* *} p<0.01,{ }^{* * *} p<0.001$ compared with control. ${ }^{\Delta} P<0.05,{ }^{\Delta \triangle} P<0.01,{ }^{\Delta \Lambda} P<0.001$ compared with respective secretagogue at control. 
TABLE 3. 1.1B4 Gene Expression After 18-Hour Exposure to Chemicals

\begin{tabular}{|c|c|c|c|c|c|}
\hline Genes & Control (Untreated) & Streptozotocin (0.5 mM) & Alloxan (0.5 mM) & Ninhydrin (0.025 mM) & $\mathrm{H}_{2} \mathrm{O}_{2}(0.03 \mathrm{mM})$ \\
\hline \multicolumn{6}{|c|}{ Secretory function } \\
\hline INS & $1.0 \pm 0.08$ & $0.31 \pm 0.15^{*}$ & $0.43 \pm 0.07 *$ & $0.31 \pm 0.18^{\dagger}$ & $0.25 \pm 0.12 *$ \\
\hline GCK & $1.0 \pm 0.13$ & $0.70 \pm 0.12^{\dagger}$ & $0.71 \pm 0.10^{\dagger}$ & $0.68 \pm 0.10$ & $0.65 \pm 0.16$ \\
\hline PCSK1 & $1.0 \pm 0.09$ & $0.25 \pm 0.14^{*}$ & $0.32 \pm 0.14^{*}$ & $5.60 \pm 0.34^{\ddagger}$ & $1.17 \pm 0.20$ \\
\hline PCSK2 & $1.0 \pm 0.15$ & $0.97 \pm 0.09$ & $0.88 \pm 0.12$ & $0.14 \pm 0.29$ & $0.13 \pm 0.36$ \\
\hline GJA1 & $1.0 \pm 0.13$ & $0.54 \pm 0.07^{\dagger}$ & $0.27 \pm 0.11^{*}$ & $0.96 \pm 0.14$ & $0.64 \pm 0.07^{\dagger}$ \\
\hline \multicolumn{6}{|c|}{ Antioxidant defense } \\
\hline SOD1 & $1.0 \pm 0.05$ & $1.29 \pm 0.08^{\dagger}$ & $1.36 \pm 0.09^{\dagger}$ & $1.36 \pm 0.09$ & $1.14 \pm 0.03$ \\
\hline SOD2 & $1.0 \pm 0.22$ & $3.38 \pm 0.20^{\ddagger}$ & $3.53 \pm 0.22^{\ddagger}$ & $1.73 \pm 0.10^{\dagger}$ & $1.82 \pm 0.10^{\dagger}$ \\
\hline CAT & $1.0 \pm 0.04$ & $1.18 \pm 0.11$ & $1.54 \pm 0.08^{*}$ & $1.66 \pm 0.08$ & $1.31 \pm 0.06^{\dagger}$ \\
\hline GPX-1 & $1.0 \pm 0.16$ & $0.92 \pm 0.18$ & $0.90 \pm 0.11$ & $0.70 \pm 0.03$ & $0.81 \pm 0.08$ \\
\hline \multicolumn{6}{|l|}{ Apoptosis } \\
\hline BCL2 & $1.0 \pm 0.03$ & $0.32 \pm 0.11^{*}$ & $0.35 \pm 0.09$ & $0.21 \pm 0.21$ & $0.13 \pm 0.27$ \\
\hline BAX & $1.0 \pm 0.10$ & $1.37 \pm 0.04^{\dagger}$ & $1.43 \pm 0.04^{\dagger}$ & $1.39 \pm 0.32$ & $1.64 \pm 0.24 *$ \\
\hline NFKB1 & $1.0 \pm 0.05$ & $1.31 \pm 0.08^{\dagger}$ & $1.33 \pm 0.12^{\dagger}$ & $1.34 \pm 0.04^{\dagger}$ & $1.29 \pm 0.06$ \\
\hline \multicolumn{6}{|l|}{ ER stress } \\
\hline HSPA4 & $1.0 \pm 0.04$ & $0.91 \pm 0.04$ & $0.74 \pm 0.06^{\dagger}$ & $1.09 \pm 0.13$ & $1.01 \pm 0.03$ \\
\hline HSPA5 & $1.0 \pm 0.05$ & $0.76 \pm 0.05^{\dagger}$ & $0.80 \pm 0.09$ & $0.89 \pm 0.14$ & $0.74 \pm 0.04^{*}$ \\
\hline $\begin{array}{l}\text { Values } \\
* P<0 . \\
{ }^{\dagger} P<0 . \\
{ }^{\star} P<0 .\end{array}$ & $\begin{array}{l}\text { mean } \pm \text { SEM }(\mathrm{n}=4) \cdot \mathrm{mF} \\
\text { compared with untreated } \\
\text { compared with untreated } \\
\text { compared with untreated }\end{array}$ & $\begin{array}{l}\text { A expression was normalized } t \\
\text { trol }(1.0) \text {. } \\
\text { trol }(1.0) \text {. } \\
\text { ntrol (1.0). }\end{array}$ & $C T B$ expression and $\mathrm{c}$ & ared with untreated control & \\
\hline
\end{tabular}

$P<0.001$; Table 3$)$. Ninhydrin $(25 \mu \mathrm{M})$ significantly increased $S O D 2$ mRNA expression, and $\mathrm{H}_{2} \mathrm{O}_{2}(30 \mu \mathrm{M})$ increased SOD2 and $C A T$ mRNA expression $(P<0.05$; Table 3$)$. Catalase enzyme activity was significantly increased in streptozotocin-treated $(0.5 \mathrm{mM})$ and ninhydrin-treated $(25 \mu \mathrm{M})$ cells, whereas it was decreased in $\mathrm{H}_{2} \mathrm{O}_{2}$-treated $(30 \mu \mathrm{M})$ cells $(P<0.05, P<0.001$; Fig. $2 \mathrm{~F})$.

\section{DNA Damage}

Representative images showing comets of 1.1B4 cells (control and chemical treated cells) are shown in Figure 4A. All chemicals significantly increased tail DNA and olive tail moment $(P<0.001$; Figs. 4B, C).
Control Streptozotocin $(0.5 \mathrm{mM})$

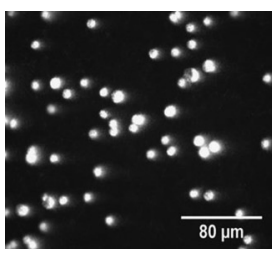

A
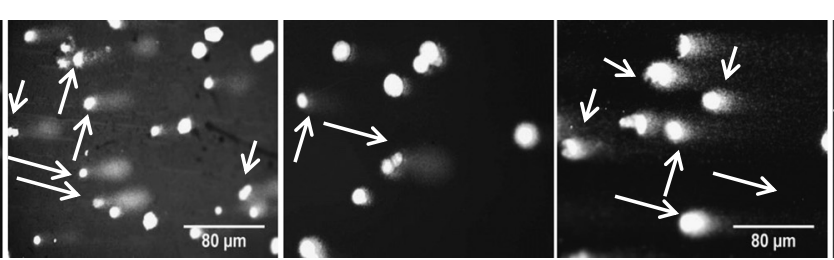

$\mathrm{H}_{2} \mathrm{O}_{2}(0.03 \mathrm{mM})$

UV (20 min)
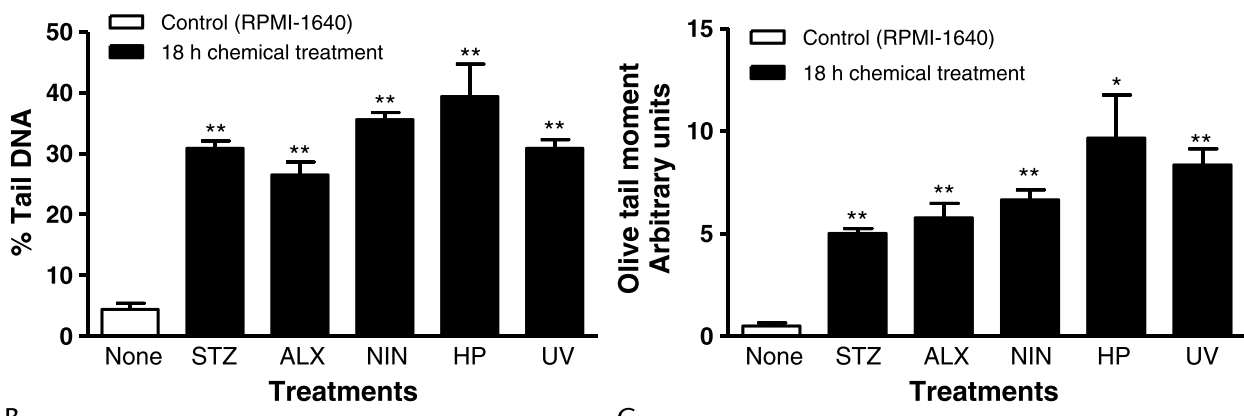

C
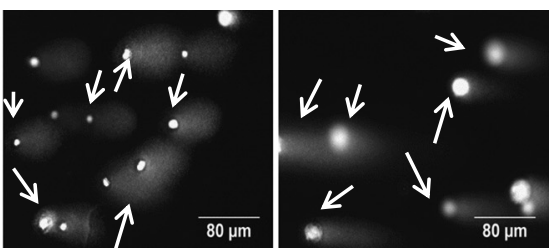

FIGURE 4. Comets of 1.1B4 cells showing extent of DNA damage following 18-hour exposure to chemicals (streptozotocin [STZ; 0.5 mM] alloxan [AX; $0.5 \mathrm{mM}$ ], ninhydrin [NIN; $25 \mu \mathrm{M}]$, hydrogen peroxide [HP; $30 \mu \mathrm{M}]$ ) (A). Arrows indicate cells with comets. \% Tail DNA (B) and olive tail moment $(C)$. Values are mean $\pm \operatorname{SEM}(n=4)$. ${ }^{*} P<0.01,{ }^{* *} P<0.001$ compared with untreated control cells.

6 | www.pancreasjournal.com

(C) 2016 Wolters Kluwer Health, Inc. All rights reserved 
Control

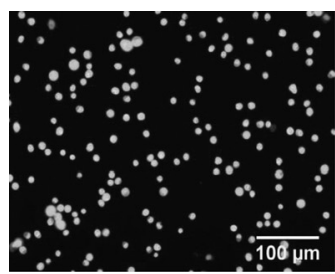

A
Streptozotocin $(0.5 \mathrm{mM})$

Alloxan (0.5 mM)

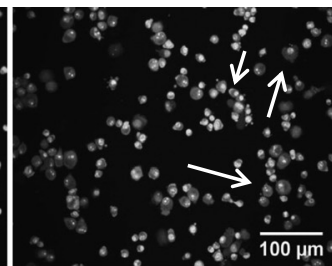

Ninhydrin (0.025 mM)

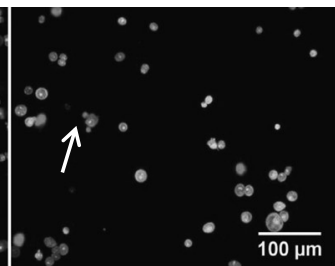

\section{Ninhydrin (0.025 mM)}

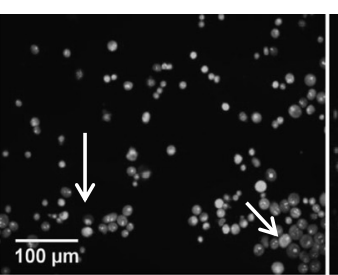

$\mathrm{H}_{2} \mathrm{O}_{2}(0.03 \mathrm{mM})$
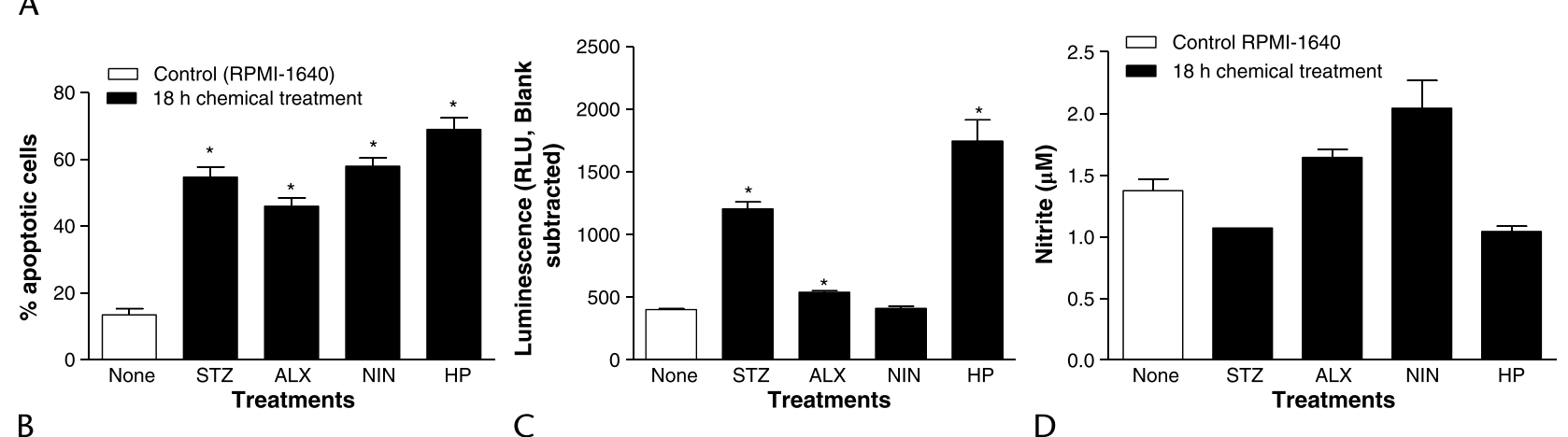

FIGURE 5. Acridine orange/ethidium bromide stained 1.1B4 cells showing extent of apoptosis following 18-hour exposure to chemicals (streptozotocin [STZ; $0.5 \mathrm{mM}$ ], alloxan [AX; $0.5 \mathrm{mM}$ ], ninhydrin [NIN; $25 \mu \mathrm{M}$ ], hydrogen peroxide [HP; $30 \mu \mathrm{M}])(\mathrm{A})$. Arrows indicate cells undergoing apoptosis. \% apoptotic cells $(B)$. Caspase $3 / 7$ activity $(C)$. Nitrite levels $(D)$. Values are mean \pm SEM $(n=4)$. ${ }^{*} P<0.001$ compared with untreated control cells.

\section{Apoptosis, Endoplasmic Reticulum Stress, and Nitrite Production}

Representative images showing acridine orange/ethidium bromide-stained 1.1B4 cells (control and chemical treated cells) are shown in Figure 5A. All chemicals significantly increased numbers of apoptotic cells $(P<0.001$; Fig. 5B). Caspase $3 / 7$ activity was significantly higher in streptozotocin-treated $(0.5 \mathrm{mM})$, alloxan-treated $(0.5 \mathrm{mM})$, and $\mathrm{H}_{2} \mathrm{O}_{2}$-treated $(30 \mu \mathrm{M})$ cells $(P<0.001$; Fig. 5C), whereas none of the chemicals affected nitrite production by $1.1 \mathrm{~B} 4$ cells (Fig. 5D). Streptozotocin $(0.5 \mathrm{mM})$ and alloxan $(0.5 \mathrm{mM})$ significantly decreased mRNA expression of $B C L 2(P<0.01, P<0.001$; Table 3$)$, whereas streptozotocin $(0.5 \mathrm{mM})$, alloxan $(0.5 \mathrm{mM})$, and $\mathrm{H}_{2} \mathrm{O}_{2}(30 \mu \mathrm{M})$ increased $B A X$ mRNA expression $(P<0.05, P<0.01$; Table 3$)$. Streptozotocin $(0.5 \mathrm{mM})$, alloxan $(0.5 \mathrm{mM})$, and ninhydrin $(25 \mu \mathrm{M})$ increased NFKB1 transcription. Streptozotocin $(0.5 \mathrm{mM})$ and $\mathrm{H}_{2} \mathrm{O}_{2}(30 \mu \mathrm{M})$ decreased HSPA5 transcription, whereas alloxan $(0.5 \mathrm{mM})$ decreased HSPA4 transcription $(P<0.05$; Table 3$)$.

\section{DISCUSSION}

Oxidative stress plays a crucial role in pathophysiology of many diseases including diabetes, neurodegenerative disorders, ischemia, atherosclerosis, rheumatoid arthritis, and cancer. ${ }^{9,22}$ Mammalian cells have protective mechanisms to scavenge excessive amounts of free radicals, the net biological response to ROS being determined by the concentration of superoxide and hydroxyl radicals, the localization and expression of antioxidant enzymes, and the posttranslational regulation of antioxidant enzymes. ${ }^{9}$ In types 1 and 2 diabetes, ROS are involved in executing pancreatic beta cell death, although the triggers are different, namely, cytokines in type 1 diabetes and chronic hyperglycemiahyperlipidemia in type 2 diabetes. Importantly, the expression level of antioxidant enzymes in pancreatic islets is approximately 20 times lower than in liver, making beta cells particularly vulnerable to damage by ROS. ${ }^{23-25}$ Indeed, previous reports on effects of chemicals including streptozotocin, alloxan, ninhydrin, and hydrogen peroxide on pancreatic beta cell models and isolated pancreatic islets suggest that oxidative stress is the main mechanism of toxicity. ${ }^{2,26,27}$ In the present study, we investigated the toxicity mechanisms in a novel human pancreatic beta cell line, 1.1B4, after chronic 18-hour exposure to these agents.

Acute or longer-term exposure to chemicals decreased 1.1B4 cell viability, with $\mathrm{LD}_{50}$ values for streptozotocin and alloxan at 60 minutes being 20 and $12 \mathrm{mM}$, respectively. This contrasts with values of approximately $5 \mathrm{mM}$ reported for MIN6 mouse insulinoma cells. ${ }^{28}$ Even lower $\mathrm{LD}_{50}$ values were observed in RINm5F and INS-1E cells, ${ }^{29}$ indicating that $1.1 \mathrm{~B} 4$ cells, like primary human beta cells, are relatively resistant to streptozotocin and alloxan toxicity when compared with rodent beta cell lines. The fact that human beta cells are susceptible only to relatively high concentrations of alloxan and streptozotocin may be attributed to low expression of GLUT2 transporter as well as greater expression of antioxidant enzymes. ${ }^{30-32}$ From gene expression studies, we observed that 1.1B4 cells demonstrated very low levels of GLUT2 mRNA (cycle threshold >32), thus confirming our results. Interestingly, 1.1B4 cells exhibited toxicity to ninhydrin and hydrogen peroxide at low concentrations, consistent with deleterious effects of these agents at 0.2 to $0.5 \mathrm{mM}$ concentrations in human islets. ${ }^{33}$ This increased sensitivity compared with alloxan and streptozotocin may be partly due to independence from GLUT2-mediated transport together with greater induction of oxidative stress.

In addition to negative effects on 1.1B4 cell viability, chemical toxins induced wide-ranging effects on beta cell function. Within 5 minutes of alloxan exposure, glucokinase activity was inhibited by alloxan because the central 5-carbonyl group reacts readily with thiol functional groups. ${ }^{2}$ Other chemicals do not directly inhibit glucokinase activity, but they indirectly affect glucokinase activity by accumulating ROS, which are toxic to proteins. On exposure of 1.1B4 cells to cytotoxins, we observed 
down-regulation of cellular insulin content and mRNA expression of multiple genes involved in secretory function. This is consistent with the idea that free radicals generated by these chemicals induce DNA damage and result in global decrease in gene expression. Chemicals (with the exception of ninhydrin) also appeared to affect cell communication, evident from the reduced mRNA expression of GJA1, a gap junction protein (connexin 43) involved in synchronizing secretory responses of pancreatic beta cells. ${ }^{34-38}$ mRNA expression of INS, GCK, PCSK1, and PCSK2 was also reduced in toxin-treated 1.1B4 cells. Such effects were reflected by reduced secretory responses to nutrients and other agents inducing membrane depolarization. Thus, chemicals affect 1.1B4 cell function by interfering with functions of crucial proteins involved in cell secretory function, glucokinase in particular, which is central to glucose oxidation. Ability of these secretagogues to enhance intracellular $\mathrm{Ca}^{2+}$ ions was also impaired. Interestingly, ability to secrete insulin in response to elevation of intracellular $\mathrm{Ca}^{2+}$ with $7.68 \mathrm{mM} \mathrm{CaCl}_{2}$ was retained, suggesting that the final events culminating in exocytosis were relatively spared.

In addition to impairing insulin secretion, chemicals exerted significant effects on mechanisms involved in 1.1B4 defense. mRNA expression of antioxidant enzymes was up-regulated in toxin-treated cells with SOD1 increased by streptozotocin and alloxan, SOD2 increased by all chemicals, and $C A T$ increased by alloxan and hydrogen peroxide. Catalase enzyme activity was found to be increased in toxin-treated cells with the exception of alloxan. Exposure to hydrogen peroxide also decreased enzyme activity possibly due to exhaustion of catalase by hydrogen peroxide. Importance of antioxidant enzymes for protection from oxidative stress has been discussed extensively in literature. ${ }^{10,39}$ Overexpression of catalase in mouse beta cells protected partially from streptozotocin and hydrogen peroxide toxicity. ${ }^{40}$ Our observations suggest that 1.1B4 cell defense mechanisms were up-regulated on exposure to chemicals but failed to protect from toxicity, apparent from our observations on DNA damage and apoptosis.

After exposure to chemicals, 1.1B4 DNA integrity was compromised, with all chemicals causing DNA fragmentation. Such effects of streptozotocin and alloxan have been reported in RINm5F cells. ${ }^{41-43}$ Excessive fragmentation of DNA interferes with gene expression and hence affects important biological processes. Depletion of cellular stores of $\mathrm{NAD}^{+}$and ATP stores by Poly ADP (Adenosine Diphosphate)-Ribose Polymerase to repair DNA activates apoptosis pathways. Transcription of $\mathrm{Bcl} 2$ was down-regulated, and that of Bax was up-regulated in 1.1B4 cells exposed to streptozotocin RINm5F cells. ${ }^{44}$ The ratio of antiapoptotic to proapoptotic factors plays a crucial role in cell survival. Mitochondrial morphology is affected by the ratio of BCL2 to BAX, with a shift toward proapoptosis leading to leakage of cytochrome c. Chemicals increased NFKB1 transcription in $1.1 \mathrm{~B} 4$ cells, thus implicating a role for nuclear factor $\kappa \mathrm{B}$ in cellular responses after exposure to chemicals. Further evaluation of the activity of nuclear factor $\mathrm{kB}$ using DNA binding studies will clarify its role in $1.1 \mathrm{~B} 4$ cell survival. However, from our observations, it was apparent that chemicals did not induce endoplasmic reticulum (ER) stress response, evident from HSPA4 and HSPA5 mRNA levels. Further studies investigating the levels of other relevant molecules in the ER stress response pathways such as phospho-EIF2 $\alpha$, ATF4, and spliced XBP-1 are needed. Caspase 3/7 activity and numbers of apoptotic cells were significantly higher in toxintreated 1.1B4 cells, suggesting execution of apoptosis.

In conclusion, this study has delineated the molecular mechanisms of toxicity and cell damage mediated in human 1.1B4

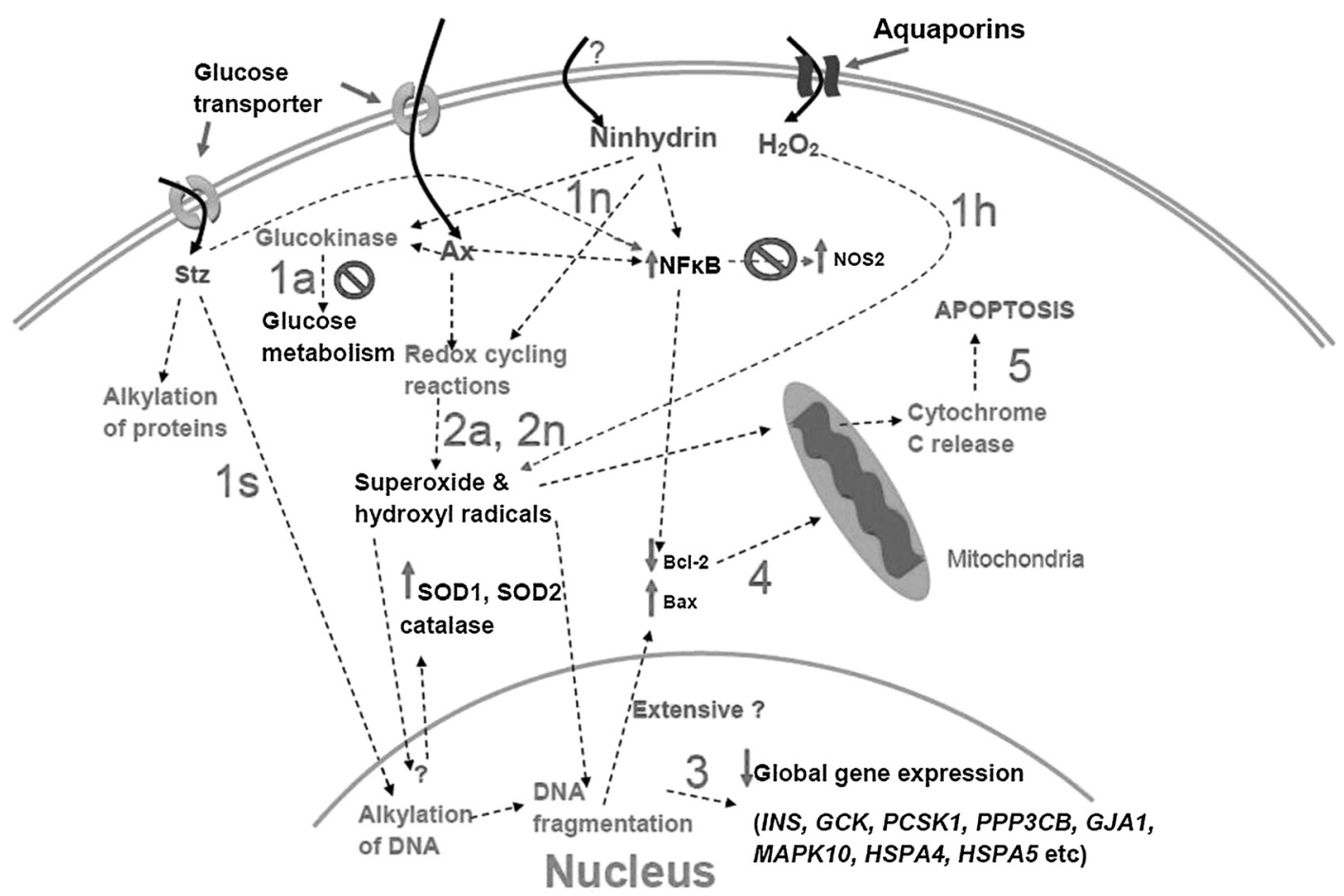

FIGURE 6. Mechanism of toxicity by chemicals in 1.1B4 cells: Streptozotocin alkylates DNA immediately after exposure and causes DNA fragmentation (1s). Alloxan inhibits glucokinase enzyme activity immediately after exposure and thus affects 1.1B4 cell function (1a). Alloxan and ninhydrin participate in redox cycling reactions $(2 \mathrm{a}, 1 \mathrm{n})$ and accumulates ROS, which cause DNA fragmentation. Hydrogen peroxide generates hydroxyl radicals by reactions with metal ions and cause DNA fragmentation $(1 \mathrm{~h})$. DNA fragmentation leads to global decrease in gene expression and activation of apoptosis in the event of excessive damage $(3,4,5)$. Figure was constructed from our observations in 1.1B4 cells and from literature. 
cells by streptozotocin, alloxan, ninhydrin, and hydrogen peroxide (Fig. 6). Further understanding of the responses and factors involved in the damage, protection, and repair of model human beta cell lines, such as human 1.1B4, may open up new avenues to the treatment and possible prevention of beta cell loss in diabetes.

\section{REFERENCES}

1. Cnop M, Welsh N, Jonas JC, et al. Mechanisms of pancreatic beta-cell death in type 1 and type 2 diabetes: many differences, few similarities. Diabetes. 2005;54 suppl 2:S97-S107.

2. Lenzen S. The mechanisms of alloxan- and streptozotocin-induced diabetes. Diabetologia. 2008;51:216-226.

3. Wilson GL, LeDoux SP. The role of chemicals in the etiology of diabetes mellitus. Toxicol Pathol. 1989;17:357-363.

4. Jorns A, Munday R, Tiedge M, et al. Comparative toxicity of alloxan, $\mathrm{N}$-alkylalloxans and ninhydrin to isolated pancreatic islets in vitro. J Endocrinol. 1997;155:283-293.

5. Elsner M, Guldbakke B, Tiedge M, et al. Relative importance of transport and alkylation for pancreatic beta-cell toxicity of streptozotocin. Diabetologia. 2000;43:1528-1533.

6. Elsner M, Tiedge M, Lenzen S. Mechanism underlying resistance of human pancreatic beta cells against toxicity of streptozotocin and alloxan. Diabetologia. 2003;46:1713-1714.

7. Eizirik DL, Sandler S, Sener A, et al. Defective catabolism of D-glucose and L-glutamine in mouse pancreatic islets maintained in culture after streptozotocin exposure. Endocrinology. 1988;123:1001-1007.

8. Rasschaert J, Eizirik DL, Malaisse WJ. Long term in vitro effects of streptozotocin, interleukin-1, and high glucose concentration on the activity of mitochondrial dehydrogenases and the secretion of insulin in pancreatic islets. Endocrinology. 1992;130:3522-3528.

9. Veal EA, Day AM, Morgan BA. Hydrogen peroxide sensing and signaling Mol Cell. 2007;26:1-14.

10. Tiedge M, Lortz S, Munday R, et al. Complementary action of antioxidant enzymes in the protection of bioengineered insulin-producing RINm5F cells against the toxicity of reactive oxygen species. Diabetes. 1998;47:1578-1585.

11. Vasu S, McClenaghan NH, McCluskey JT, et al. Effects of lipotoxicity on a novel insulin-secreting human pancreatic $\beta$-cell line, 1.1B4. Biol Chem 2013;394:909-918.

12. Vasu S, McClenaghan NH, McCluskey JT, et al. Cellular responses of novel human pancreatic $\beta$-cell line, 1.1B4 to hyperglycemia. Islets. 2013;5:170-177.

13. Vasu S, McClenaghan NH, McCluskey JT, et al. Mechanisms of toxicity by proinflammatory cytokines in a novel human pancreatic beta cell line, 1.1B4. Biochim Biophys Acta. 2014;1840:136-145.

14. McCluskey JT, Hamid M, Guo-Parke H, et al. Development and functional characterization of insulin-releasing human pancreatic beta cell lines produced by electrofusion. J Biol Chem. 2011;286:21982-21992.

15. Guo-Parke H, McCluskey JT, Kelly C, et al. Configuration of electrofusion derived human insulin-secreting cell line as pseudoislets enhances functionality and therapeutic utility. $J$ Endocrinol. 2012;214:257-265.

16. Green $\mathrm{AD}$, Vasu S, McClenaghan $\mathrm{NH}$, et al. Pseudoislet formation enhances gene expression, insulin secretion and cytoprotective mechanisms of clonal human insulin-secreting 1.1B4 cells. Pflugers Arch 2015;467:2219-2228.

17. Mosmann T. Rapid colorimetric assay for cellular growth and survival: application to proliferation and cytotoxicity assays. J Immunol Methods. 1983;65:55-63.

18. Flatt PR, Bailey CJ. Abnormal plasma glucose and insulin responses in heterozygous lean (ob/+) mice. Diabetologia. 1981;20:573-577.
19. Miguel JC, Patterson S, Abdel-Wahab YH, et al. Time-correlation between membrane depolarization and intracellular calcium in insulin secreting BRIN-BD11 cells: studies using FLIPR. Cell Calcium. 2004;36:43-50.

20. Lenzen S, Tiedge M, Flatt PR, et al. Defective regulation of glucokinase in rat pancreatic islet cell tumours. Acta Endocrinol (Copenh). 1987;115: 514-520.

21. Lees Murdock DJ, Barnett YA, Barnett CR, et al. DNA damage and cytotoxicity in pancreatic beta-cells expressing human CYP2E1. Biochem Pharmacol. 2004;68:523-530.

22. Jang JS, Lee JS, Lee JH, et al. Hispidin produced from phellinus linteus protects pancreatic beta-cells from damage by hydrogen peroxide. Arch Pharm Res. 2010;33:853-861.

23. Kimoto K, Suzuki K, Kizaki T, et al. Gliclazide protects pancreatic beta-cells from damage by hydrogen peroxide. Biochem Biophys Res Commun. 2003;303:112-119.

24. Maechler P, Jornot L, Wollheim CB. Hydrogen peroxide alters mitochondrial activation and insulin secretion in pancreatic beta cells. J Biol Chem. 1999;274:27905-27913.

25. Mechlovich D, Amit T, Mandel SA, et al. The novel multifunctional, iron-chelating drugs M30 and HLA20 protect pancreatic beta-cell lines from oxidative stress damage. J Pharmacol Exp Ther. 2010;333: 874-882.

26. Picton SF, McCluskey JT, Flatt PR, et al. Effects of cytotoxic agents on functional integrity and antioxidant enzymes in clonal beta-cells. Diabetes Metab. 2002;28:3S70-3S77.

27. Taniguchi S, Kang L, Kimura T, et al. Hydrogen sulphide protects mouse pancreatic $\beta$-cells from cell death induced by oxidative stress, but not by endoplasmic reticulum stress. Br J Pharmacol. 2011;162: 1171-1178.

28. Vasu S, Moffett RC, McClenaghan NH, et al. Responses of GLP1-secreting $\mathrm{L}$-cells to cytotoxicity resemble pancreatic $\beta$-cells but not $\alpha$-cells. $J \mathrm{Mol}$ Endocrinol. 2015;54:91-104.

29. Guan N, Gao W, He M, et al. Dynamic monitoring of $\beta$-cell injury with impedance and rescue by glucagon-like peptide-1. Anal Biochem. 2012; 423:61-69.

30. Eizirik DL, Pipeleers DG, Ling Z, et al. Major species differences between humans and rodents in the susceptibility to pancreatic beta-cell injury. Proc Natl Acad Sci U S A. 1994;91:9253-9256.

31. Tyrberg B, Eizirik DL, Marklund SL, et al. Human islets in mixed islet grafts protect mouse pancreatic beta-cells from alloxan toxicity. Pharmacol Toxicol. 1999;85:269-275.

32. Welsh N, Margulis B, Borg LA, et al. Differences in the expression of heat-shock proteins and antioxidant enzymes between human and rodent pancreatic islets: implications for the pathogenesis of insulin-dependent diabetes mellitus. Mol Med. 1995;1:806-820.

33. Hoorens A, Pipeleers D. Nicotinamide protects human beta cells against chemically-induced necrosis, but not against cytokine-induced apoptosis. Diabetologia. 1999;42:55-59.

34. Hauge-Evans AC, Squires PE, Persaud SJ, et al. Pancreatic beta-cell-tobeta-cell interactions are required for integrated responses to nutrient stimuli: enhanced $\mathrm{Ca}^{2+}$ and insulin secretory responses of MIN6 pseudoislets. Diabetes. 1999;48:1402-1408.

35. Heit JJ, Apelqvist AA, Gu X, et al. Calcineurin/NFAT signalling regulates pancreatic beta-cell growth and function. Nature. 2006;443: 345-349.

36. Klee $\mathrm{P}$, Allagnat $\mathrm{F}$, Pontes $\mathrm{H}$, et al. Connexins protect mouse pancreatic $\beta$ cells against apoptosis. $J$ Clin Invest. 2011;121:4870-4879.

37. Sato T, Haimovici R, Kao R, et al. Downregulation of connexin 43 expression by high glucose reduces gap junction activity in microvascular endothelial cells. Diabetes. 2002;51:1565-1571. 
38. Vozzi C, Ullrich S, Charollais A, et al. Adequate connexin-mediated coupling is required for proper insulin production. J Cell Biol. 1995;131: $1561-1572$.

39. Mathews CE, Leiter EH. Constitutive differences in antioxidant defense status distinguish alloxan-resistant and alloxan-susceptible mice. Free Radic Biol Med. 1999;27:449-455.

40. Xu B, Moritz JT, Epstein PN. Overexpression of catalase provides partial protection to transgenic mouse beta cells. Free Radic Biol Med. 1999;27:830-837.

41. Takasu N, Komiya I, Asawa T, et al. Streptozocin- and alloxan-induced $\mathrm{H}_{2} \mathrm{O}_{2}$ generation and DNA fragmentation in pancreatic islets. $\mathrm{H}_{2} \mathrm{O}_{2}$ as mediator for DNA fragmentation. Diabetes. 1991;40:1141-1145.
42. Koo KB, Suh HJ, Ra KS, et al. Protective effect of cyclo(his-pro) on streptozotocin-induced cytotoxicity and apoptosis in vitro. J Microbiol Biotechnol. 2011;21:218-227.

43. Zhang R, Kim JS, Kang KA, et al. Protective mechanism of KIOM-4 in streptozotocin-induced pancreatic $\beta$-cells damage is involved in the inhibition of endoplasmic reticulum stress. Evid Based Complement Alternat Med. 2011;2011: 231938.

44. Onoue S, Hanato J, Yamada S. Pituitary adenylate cyclase-activating polypeptide attenuates streptozotocin-induced apoptotic death of RIN-m5F cells through regulation of bcl-2 family protein mRNA expression. FEBS J. 2008;275:5542-5551. 